\title{
Relation between Theophylline Serum Level with ECG Changes and Poison Severity Score (PSS) Among Some Theophylline Intoxicated Patients in Menofia Poison Control Center (MPCC) A Prospective Study
}

\author{
Safaa Abd Elzaher Amin, Amira Mohamed El Seidy, Samy Abd EL-Hady \\ Hammad, and Nagwa Mahmoud Habib1
}

\footnotetext{
${ }^{1}$ Department of Forensic Medicine and Clinical Toxicology, Faculty of Medicine, Menoufia University, Shibin Al Kawm, Egypt.
}

\begin{abstract}
There are numerous toxins and drugs that can cause, in overdose, ECG changes, even in patients without history of cardiac pathology. Theophylline intoxication results in substantial morbidity and mortality, particularly in those with chronic overmedication. The aim of this work was to study ECG changes in cases of poisoning by theophylline overdose that were admitted to MPCC over 2011 and the relation between ECG changes, theophylline blood level and poison severity score. In this study, theophylline overdose patients admitted to MPCC in the period from $1^{\text {st }}$ of January 2011 to $31^{\text {st }}$ of December 2011 were included. The total patients' number was 44 patients. Most cases of the study were females $(77.2 \%)$ in the age group of $(20-<40)$ years $(40.9 \%)$, mainly from rural side $(65.9 \%)$. Regarding relation between theophylline serum level and clinical manifestations, a significant relation was found between serum level and each of vomiting and dizziness, where both were noticed with majority of cases of minimal and moderate toxicity serum level. Regarding poison severity score, exactly one half of moderate and severe cases had minimal toxicity serum level, and the other half had moderate toxicity level. A significant negative correlation between theophylline serum level and $\mathrm{PCO}_{2}$ was found. There was a non significant negative correlation between theophylline serum level and each of $\mathrm{Na}$ and $\mathrm{K}$ blood level. Concerning ECG changes, a significant relation was found between theophylline serum level and each of sinus tachycardia and second degree heart block.
\end{abstract}

Keywords Theophylline, poison, ECG, Poison Severity Score, Chemiluminescent immunoassay

\section{Introduction}

$\mathrm{T}$ There are numerous toxins and drugs that can cause, in overdose, ECG changes, even in patients without history of cardiac pathology (Lionte et al., 2012). Cardiac dysrhythmia (also known as arrhythmia) is a term for any of a large and heterogeneous group of conditions in which there is abnormal electrical activity in the heart (Sköld, 2000). Theophylline (1, 3-dimethylxanthine), is a proven bronchodilator drug used in therapy for respiratory diseases such as asthma or chronic obstructive pulmonary disease (COPD) (Cazzola and Matera, 2007). The occurrence of adverse effects with theophylline, even at levels in the therapeutic range, and the severity of its effects in acute and chronic overdose are notable (Reillyand Stawicki 2008). Theophylline intoxication results in substantial morbidity and mortality, particularly in those with chronic overdosage (Shannon, 1999). The major clinical effects of theophylline at both therapeutic and overdose result from adenosine antagonism, release of endogenous norepinephrine, and consequent adrenergic receptor stimulation and phosphodiesterase inhibition (Hoffman, 2006). Theophylline toxic reactions including nausea, vomiting, headache, diarrhea, irritability and insomnia, increase if the theophylline level exceeds $20 \mu \mathrm{g} / \mathrm{ml}$. At higher concentrations, there is a progressive increase of risk of toxic encephalopathy with hyperthermia, seizures, brain damage and death. Hyperglycemia, hypokalemia, hypertension and cardiac arrhythmia may also be observed at these higher levels (Visitsunthorn et al., 2001; Yoshikawa, 2007; Lionte et al., 2012). The aim 
of this work is to study ECG changes in cases of theophylline poisoning that were admitted to MPCC through the year 2011 and the relation between these changes and poison severity score.

\section{Patients, Material and Methods}

In this study, patients giving history of theophylline overdose and admitted to MPCC in the period from $1^{\text {st }}$ of January 2011 to $31^{\text {st }}$ of December 2011 were included. The study was carried out in an ethical manner following guidelines set by the Ethical Committee of Menofia University. Informed valid consent was taken from the patients (or the patient's guardian) before the study.

The demographic and clinical data were collected from each patient in a designed clinical toxicological sheet. Patients suffering from any systemic diseases, cardiac illness, any co- ingestions, past history of ECG changes and who did not give informed consent were excluded from the study.

Blood pressure, heart rate, blood electrolytes, arterial blood gas and liver and kidney function tests were compared with age-matched control values (Kliegman et al., 2008; Verma and Roach, 2010) At least one ECG tracing was done for each patient to be included in the study.

Blood samples were collected from patients on admission and theophylline serum level was measured by Chemiluminescent Immunoassay (CLIA) (Zhou et al., 2005). Chemiluminescent immunoassay Instrument was Access analyzer manufactured by the Beckman-Coulter Company in USA in cooperation with Pasture Academe in France. Fluorescence polarization immunoassay Instrument was TDX manufactured by the Abbott Company, USA

The studied cases were categorized according to the theophylline level as follows: mild toxicity (theophylline serum level $20-<40 \mu \mathrm{g} / \mathrm{ml}$, moderate toxicity $(40-<100 \mu \mathrm{g} / \mathrm{ml})$, severe toxicity $(\geq 100 \mu \mathrm{g} / \mathrm{ml})$ (Torraca and Wang, 1998), and therapeutic theophylline level (10-20 $\mu \mathrm{g} / \mathrm{ml})$ (Nolan et al., 2005).

Again studied cases were classified according to poison severity score. The clinical severity of poisoning was graded according to the method described by Persson and coworkers, and developed by the International Program on Chemical Safety, the European Community, and the European Association of Poisons Centers and Clinical Toxicologists (IPCS/EC/EAPCCT) (Fruchtengarten, 2006). The poisoning severity score (PSS) is a four-scale grading as (0) none, (1) minor, (2) moderate, (3) severe, and (4) fatal. It was determined at the time of initial inquiry and following recovery, using examination findings including the Glasgow coma score, pupil size, convulsion, respiratory rate, pulse rate, blood pressure, body temperature, ECG findings, pain assessment, and laboratory presentations (serum glucose, potassium, sodium, $\mathrm{pH}$, and bicarbonate in arterial blood gases) (Persson et al., 1998).

Statistical parameters to analyze the qualitative findings were applied by using chi-square $\left(\chi^{2}\right)$. Pearson's Correlation Coefficient test was applied to test the correlation between the studied parameters. (Elliott and Woodward, 2007; Hansen et al., 2009).

\section{Results}

During the duration from $1^{\text {st }}$ of January 2011 to $31^{\text {st }}$ of December 2011 the total number of theophylline poisoned patients admitted to MPCC patients was 44 .

The age group of $20-<40$ years was the largest, the least was age group of $\geq 40$ yrs. Female patients constituted then majority $(77.2 \%)$. Most cases were from rural side $(65.9 \%)$ as showed in table (1). Table (2) demonstrated the relation between mode of exposure and both age and gender, where accidental poisoning was detected in the age group $5-<10$, while suicidal mode of poisoning occurred in patients aged $\geq 10$ years. The relation between age and mode of poisoning was highly significant $(\mathrm{p}<0.001)$. As regards the relation between gender and mode of poisoning, $87.9 \%$ of female cases were suicidal and $45.5 \%$ were accidental, on the other hand, $54.5 \%$ male cases were accidental and $12.1 \%$ were suicidal and the relation was significant $(\mathrm{p}=0.004)$.

Table (3) showed that most of theophylline overdose cases had a minimal toxicity theophylline serum level $(20-<40 \mu \mathrm{g} / \mathrm{ml})$ representing $79.5 \%$, followed by $11.4 \%$ had a therapeutic theophylline serum level $(<20 \mu \mathrm{g} / \mathrm{ml})$. Only $9.1 \%$ of the cases had a moderate toxicity level $(40-<100 \mu \mathrm{g} / \mathrm{ml})$ and no cases had a severe toxicity level.

A highly significant relation between the serum level and vomiting was found ( $\mathrm{P}$ value $<0.001$ ), where all 44 cases that had level within therapeutic range didn't complain of vomiting. On the other hand, vomiting was evident in $80 \%$ of cases with minimal toxicity theophylline level and in $100 \%$ of cases with moderate toxicity level.

Similar results were found with dizziness, which was not a complaint of cases with a therapeutic serum theophylline level. On the contrary, dizziness was an evident complaint in cases of minimal and moderate toxicity theophylline levels representing $28.6 \%$ and $100 \%$ of cases respectively (Table 4 ).

Table (5) showed the highly significant relation between theophylline serum level and severity grades of the studied cases according to PSS (P value $<0.001$ ), where all cases of the "none" grade of severity score had a therapeutic serum level, and all minor cases had minimal toxicity serum theophylline level. On the other hand, exactly one half of moderate and severe cases had minimal toxicity serum level, and the other half had moderate toxicity level.

Mild correlation was found between theophylline serum level and $\mathrm{P}_{\mathrm{CO} 2}(\mathrm{P}$ value $=0.03)$ (Fig. 1).

The Table (6) revealed a positive correlation between theophylline serum level and each of $\mathrm{Ca}$ blood level, $\mathrm{pH}$ of the blood and $\mathrm{HCO} 3$, which was nonsignificant.

There was a negative correlation between theophylline serum level and both $\mathrm{Na}^{+}$and $\mathrm{K}^{+}$blood level, but also was non- significant. 
A significant relation $(\mathrm{P}=0.02)$ was found between serum theophylline level and sinus tachycardia in all cases with moderate toxicity theophylline serum level, followed by cases with minimal toxicity level $(74.3 \%)$ and cases with therapeutic level $(20 \%)$.
The relation between serum theophylline level and $2^{\text {nd }}$ degree heart block was significant $(\mathrm{P}$ value $=$ 0.006). $2^{\text {nd }}$ degree heart block was found in $25 \%$ of cases with moderate toxicity theophylline serum level (Table 7) and (Figs. 2, 3, 4, 5).

Table 1: Percentage of the sociodemographic parameters among theophylline intoxicated cases.

\begin{tabular}{|l|c|c|}
\hline \multirow{2}{*}{$\begin{array}{l}\text { Age } \\
\text { (Mean } \pm \text { SD) }\end{array}$} & \multicolumn{2}{|c|}{$\begin{array}{c}\text { Studied group } \\
\mathbf{n}=\mathbf{4 4}\end{array}$} \\
Range & \multicolumn{2}{|c|}{$18.5 \pm 11.9$} \\
\hline Age (in years) & $\mathbf{n}$ & $\mathbf{\%}$ \\
\cline { 2 - 3 } & & \\
$<5$ & 7 & 15.9 \\
$5-<10$ & 4 & 9 \\
$10-<20$ & 12 & 27.2 \\
$20-<40$ & 18 & 40.9 \\
$\geq 40$ & 3 & 6.8 \\
\hline Gender & & \\
Male & 10 & 22.8 \\
female & 34 & 77.2 \\
\hline Residence & & \\
Rural & 29 & 65.9 \\
Urban & 15 & 34.1 \\
\hline
\end{tabular}

Table 2: Chisquare $\left(\chi^{2}\right)$ and Fisher's Exact test, statistical analysis of mode of exposure vs. age and gender among theophylline intoxicated patients $(n=44)$.

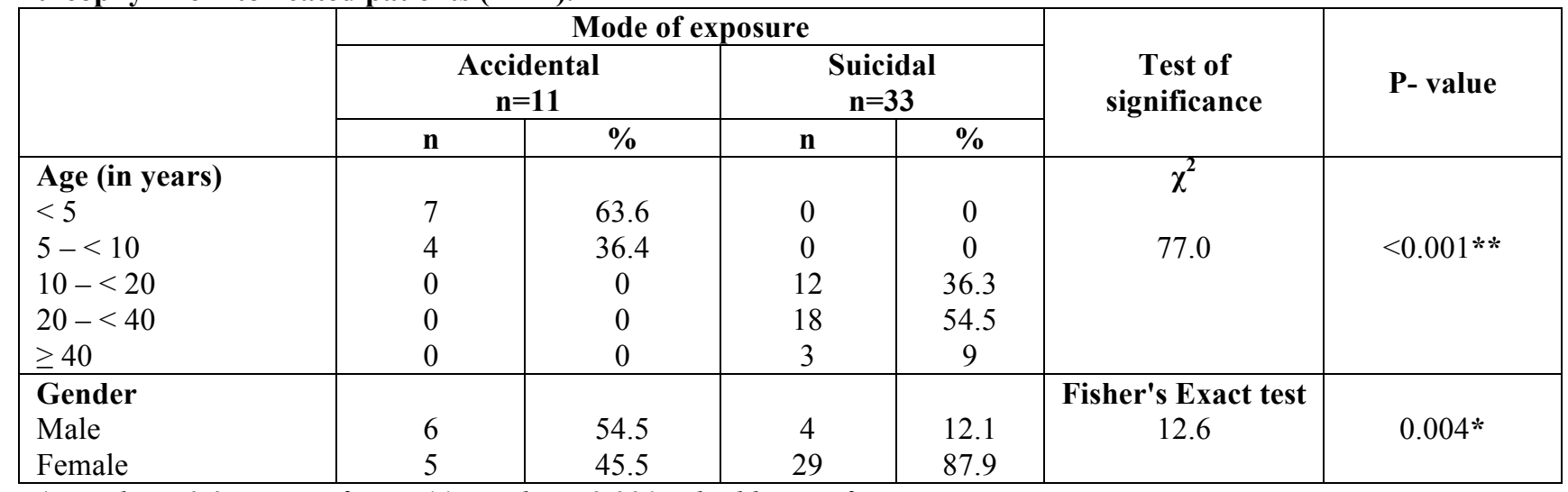

$* P$ value $<0.05=$ significant, $* * P$ value $<0.001=$ highly significant

Table 3: Distribution of the studied cases according to drug serum level.

\begin{tabular}{|l|c|c|}
\hline Theophylline serum level $(\mathbf{n}=\mathbf{4 4})$ & \multicolumn{2}{|c|}{$29.3 \pm 14.4$} \\
$($ Mean \pm SD) $(\mathrm{ug} / \mathrm{mL})$ & \multicolumn{2}{|c|}{$2-75$} \\
Range & $\mathbf{N}$ & $\mathbf{\%}$ \\
\cline { 2 - 3 } Theophylline serum level $(\boldsymbol{\mu g} / \mathbf{m l})$ & 5 & 11.4 \\
$<20$ & 35 & 79.5 \\
$20-<40$ & 4 & 9.1 \\
$40-<100$ & 0 & 0 \\
$\geq 100$ & & \\
\hline
\end{tabular}


Table 4: Chisquare $\left(\chi^{2}\right)$ statistical analysis of different clinical manifestations vs. theophylline serum level in the studied cases $(n=44)$.

\begin{tabular}{|c|c|c|c|c|c|c|c|c|}
\hline & \multicolumn{6}{|c|}{ Theophylline level $(\mu \mathrm{g} / \mathrm{ml})$} & \multirow{3}{*}{$\begin{array}{c}\text { Test of } \\
\text { significance } \\
\chi^{2}\end{array}$} & \multirow{3}{*}{$P$ value } \\
\hline & \multicolumn{2}{|c|}{$\begin{array}{l}\text { Therapeutic } \\
n=5\end{array}$} & \multicolumn{2}{|c|}{$\begin{array}{c}\text { Minimal } \\
\mathbf{n}=\mathbf{3 5}\end{array}$} & \multicolumn{2}{|c|}{$\begin{array}{c}\text { Moderate } \\
n=4\end{array}$} & & \\
\hline & $\mathbf{n}$ & $\%$ & $\mathbf{n}$ & $\%$ & $\mathbf{n}$ & $\%$ & & \\
\hline $\begin{array}{l}\text { Vomiting } \\
\text { Yes } \\
\text { No } \\
\end{array}$ & $\begin{array}{l}0 \\
5 \\
\end{array}$ & $\begin{array}{c}0 \\
100 \\
\end{array}$ & $\begin{array}{c}28 \\
7 \\
\end{array}$ & $\begin{array}{l}80 \\
20 \\
\end{array}$ & $\begin{array}{l}4 \\
0 \\
\end{array}$ & $\begin{array}{c}100 \\
0 \\
\end{array}$ & 15.77 & $\begin{array}{c}* * \\
<0.001\end{array}$ \\
\hline $\begin{array}{l}\text { Abdominal pain } \\
\text { Yes } \\
\text { No } \\
\end{array}$ & $\begin{array}{l}0 \\
5 \\
\end{array}$ & $\begin{array}{c}0 \\
100 \\
\end{array}$ & $\begin{array}{c}8 \\
27 \\
\end{array}$ & $\begin{array}{l}22.9 \\
77.1 \\
\end{array}$ & $\begin{array}{l}2 \\
2 \\
\end{array}$ & $\begin{array}{l}50 \\
50 \\
\end{array}$ & 3.17 & 0.21 \\
\hline $\begin{array}{l}\text { Diarrhea } \\
\text { Yes } \\
\text { No }\end{array}$ & $\begin{array}{l}0 \\
5\end{array}$ & $\begin{array}{c}0 \\
100\end{array}$ & $\begin{array}{c}0 \\
35\end{array}$ & $\begin{array}{r}0 \\
100 \\
\end{array}$ & $\begin{array}{l}0 \\
4\end{array}$ & $\begin{array}{r}0 \\
100 \\
\end{array}$ & ---- & ---- \\
\hline $\begin{array}{l}\text { Loss of consciousness } \\
\text { Yes } \\
\text { No }\end{array}$ & $\begin{array}{l}0 \\
5\end{array}$ & $\begin{array}{c}0 \\
100\end{array}$ & $\begin{array}{c}1 \\
34 \\
\end{array}$ & $\begin{array}{l}2.9 \\
97.1 \\
\end{array}$ & $\begin{array}{l}0 \\
4\end{array}$ & $\begin{array}{r}0 \\
100 \\
\end{array}$ & 0.26 & 0.88 \\
\hline $\begin{array}{l}\text { Dizziness } \\
\text { Yes } \\
\text { No } \\
\end{array}$ & $\begin{array}{l}0 \\
5 \\
\end{array}$ & $\begin{array}{c}0 \\
100 \\
\end{array}$ & $\begin{array}{l}10 \\
25 \\
\end{array}$ & $\begin{array}{l}28.6 \\
71.4 \\
\end{array}$ & $\begin{array}{l}4 \\
0 \\
\end{array}$ & $\begin{array}{c}100 \\
0 \\
\end{array}$ & 11.08 & $\begin{array}{c}* \\
0.004\end{array}$ \\
\hline $\begin{array}{l}\text { Convulsions } \\
\text { Yes } \\
\text { No }\end{array}$ & $\begin{array}{l}0 \\
5\end{array}$ & $\begin{array}{c}0 \\
100\end{array}$ & $\begin{array}{c}0 \\
35 \\
\end{array}$ & $\begin{array}{r}0 \\
100 \\
\end{array}$ & $\begin{array}{l}0 \\
4 \\
\end{array}$ & $\begin{array}{r}0 \\
100 \\
\end{array}$ & ---- & ---- \\
\hline $\begin{array}{l}\text { Palpitations } \\
\text { Yes } \\
\text { No }\end{array}$ & $\begin{array}{l}0 \\
5\end{array}$ & $\begin{array}{c}0 \\
100\end{array}$ & $\begin{array}{c}1 \\
34\end{array}$ & $\begin{array}{l}2.9 \\
97.1\end{array}$ & $\begin{array}{l}0 \\
4\end{array}$ & $\begin{array}{r}0 \\
100\end{array}$ & 0.26 & 0.88 \\
\hline $\begin{array}{l}\text { Difficult breathing } \\
\text { Yes } \\
\text { No }\end{array}$ & $\begin{array}{l}0 \\
5\end{array}$ & $\begin{array}{c}0 \\
100\end{array}$ & $\begin{array}{c}1 \\
34 \\
\end{array}$ & $\begin{array}{l}2.9 \\
97.1 \\
\end{array}$ & $\begin{array}{l}0 \\
4 \\
\end{array}$ & $\begin{array}{r}0 \\
100 \\
\end{array}$ & 0.26 & 0.88 \\
\hline $\begin{array}{l}\text { Abnormal behavior } \\
\text { Yes } \\
\text { No }\end{array}$ & $\begin{array}{l}0 \\
5\end{array}$ & $\begin{array}{c}0 \\
100 \\
\end{array}$ & $\begin{array}{c}0 \\
35 \\
\end{array}$ & $\begin{array}{r}0 \\
100 \\
\end{array}$ & $\begin{array}{l}0 \\
4 \\
\end{array}$ & $\begin{array}{r}0 \\
100 \\
\end{array}$ & ---- & ---- \\
\hline
\end{tabular}

$* P$ value $<0.05=$ significant,$* *$ P value $<0.001=$ highly significant

Table 5: Chisquare $\left(\chi^{2}\right)$ statistical analysis of severity grades according to PSS vs. theophylline serum level in the studied cases $(n=44)$.

\begin{tabular}{|c|c|c|c|c|c|c|c|c|}
\hline \multirow{3}{*}{$\begin{array}{c}\text { Theophylline level } \\
(\mu \mathrm{g} / \mathrm{ml})\end{array}$} & \multicolumn{6}{|c|}{ Poison severity score (PSS) } & \multirow{3}{*}{$\begin{array}{c}\text { Test of } \\
\text { significance } \\
\chi^{2}\end{array}$} & \multirow{3}{*}{$\begin{array}{c}\mathbf{P} \\
\text { value }\end{array}$} \\
\hline & \multicolumn{2}{|c|}{ None $(n=5)$} & \multicolumn{2}{|c|}{ Minor $(n=31)$} & \multicolumn{2}{|c|}{ Moderate and severe $(n=8)$} & & \\
\hline & $\mathbf{n}$ & $\%$ & $\mathbf{n}$ & $\%$ & $\mathbf{n}$ & $\%$ & & \\
\hline Therapeutic & 5 & 100 & 0 & 0 & 0 & 0 & \multirow{3}{*}{63.5} & \multirow{3}{*}{$\begin{array}{c}* * \\
<0.001\end{array}$} \\
\hline Minimal & 0 & 0 & 31 & 1000 & 4 & 50 & & \\
\hline Moderate & 0 & 0 & 0 & & 4 & 50 & & \\
\hline
\end{tabular}

$* P$ value $<0.05=$ significant,$* * P$ value $<0.001=$ highly significant

Table 6: Pearson's Correlation between theophylline serum level and some blood parameters.

\begin{tabular}{|l|c|c|}
\hline \multirow{2}{*}{} & Correlation coefficient $(\mathbf{r})$ & P value \\
\cline { 2 - 3 } & -0.13 & 0.40 \\
\hline $\mathrm{Na}(\mathrm{mEq} / \mathrm{L})$ & -0.22 & 0.16 \\
\hline $\mathrm{Ca}(\mathrm{mg} / \mathrm{dL})$ & 0.19 & 0.22 \\
\hline $\mathrm{pH}$ & 0.02 & 0.92 \\
\hline $\mathrm{PCO} 2(\mathrm{~mm} \mathrm{Hg})$ & -0.33 & $*$ \\
\hline $\mathrm{HCO}_{3}(\mathrm{mEq} / \mathrm{L})$ & & 0.03 \\
\hline
\end{tabular}

- Pearson correlation $(r):<0.3=$ no correlation, $0.3-0.5=$ mild correlation, $0.5-0.7=$ moderate correlation, $>0.7=$ strong correlation.

- Level of significance was set as P value $<0.05$ 
Table 7: Chisquare $\left(\chi^{2}\right)$ statistical analysis of ECG changes vs. theophylline serum level in studied cases (n=44).

\begin{tabular}{|c|c|c|c|c|c|c|c|c|}
\hline & \multicolumn{6}{|c|}{ Theophylline level $(\mu \mathrm{g} / \mathrm{ml})$} & \multirow{3}{*}{$\begin{array}{c}\text { Test of } \\
\text { significance } \\
\chi^{2}\end{array}$} & \multirow{3}{*}{$P$ value } \\
\hline & \multicolumn{2}{|c|}{$\begin{array}{c}\text { Therapeutic } \\
n=5\end{array}$} & \multicolumn{2}{|c|}{$\begin{array}{c}\text { Minimal } \\
\mathbf{n}=\mathbf{3 5}\end{array}$} & \multicolumn{2}{|c|}{$\begin{array}{c}\text { Moderate } \\
n=4\end{array}$} & & \\
\hline & $\mathbf{n}$ & $\%$ & $\mathbf{n}$ & $\%$ & $\mathbf{n}$ & $\%$ & & \\
\hline $\begin{array}{l}\text { Sinus bradycardia } \\
\text { Yes } \\
\text { No }\end{array}$ & $\begin{array}{l}0 \\
5\end{array}$ & $\begin{array}{c}0 \\
100\end{array}$ & $\begin{array}{l}0 \\
35\end{array}$ & $\begin{array}{r}0 \\
100\end{array}$ & $\begin{array}{l}0 \\
4\end{array}$ & $\begin{array}{r}0 \\
100\end{array}$ & ---- & ---- \\
\hline $\begin{array}{l}\text { Extrasystole } \\
\text { Yes } \\
\text { No }\end{array}$ & $\begin{array}{l}0 \\
5\end{array}$ & $\begin{array}{c}0 \\
100\end{array}$ & $\begin{array}{l}4 \\
31\end{array}$ & $\begin{array}{l}11.4 \\
88.6\end{array}$ & $\begin{array}{l}0 \\
4\end{array}$ & $\begin{array}{r}0 \\
100\end{array}$ & 1.13 & 0.57 \\
\hline $\begin{array}{l}\text { Sinus tachycardia } \\
\text { Yes } \\
\text { No }\end{array}$ & $\begin{array}{l}1 \\
4\end{array}$ & $\begin{array}{l}20 \\
80\end{array}$ & $\begin{array}{l}26 \\
9\end{array}$ & $\begin{array}{c}74.3 \\
25.7\end{array}$ & $\begin{array}{l}4 \\
0\end{array}$ & $\begin{array}{l}100 \\
0\end{array}$ & 8.04 & $0.02 *$ \\
\hline $\begin{array}{l}\text { Atrial Fibrillation } \\
\text { Yes } \\
\text { No } \\
\end{array}$ & $\begin{array}{l}0 \\
5\end{array}$ & $\begin{array}{c}0 \\
100 \\
\end{array}$ & $\begin{array}{l}1 \\
34 \\
\end{array}$ & $\begin{array}{r}2.9 \\
97.1 \\
\end{array}$ & $\begin{array}{l}1 \\
3 \\
\end{array}$ & $\begin{array}{l}25 \\
75 \\
\end{array}$ & 4.33 & 0.12 \\
\hline $\begin{array}{l}\text { S-T depression } \\
\text { Yes } \\
\text { No }\end{array}$ & $\begin{array}{l}0 \\
5\end{array}$ & $\begin{array}{c}0 \\
100\end{array}$ & $\begin{array}{l}0 \\
35\end{array}$ & $\begin{array}{r}0 \\
100\end{array}$ & $\begin{array}{l}0 \\
4\end{array}$ & $\begin{array}{r}0 \\
100\end{array}$ & ---- & ---- \\
\hline $\begin{array}{l}\text { Wide QRS } \\
\text { Yes } \\
\text { No }\end{array}$ & $\begin{array}{l}0 \\
5\end{array}$ & $\begin{array}{c}0 \\
100\end{array}$ & $\begin{array}{l}1 \\
34\end{array}$ & $\begin{array}{r}2.9 \\
97.1\end{array}$ & $\begin{array}{l}0 \\
4\end{array}$ & $\begin{array}{r}0 \\
100\end{array}$ & 0.26 & 0.88 \\
\hline $\begin{array}{l}\mathbf{1}^{\text {st }} \text { degree heart block } \\
\text { Yes } \\
\text { No }\end{array}$ & $\begin{array}{l}0 \\
5\end{array}$ & $\begin{array}{c}0 \\
100\end{array}$ & $\begin{array}{l}1 \\
34\end{array}$ & $\begin{array}{r}2.9 \\
97.1\end{array}$ & $\begin{array}{l}1 \\
3\end{array}$ & $\begin{array}{c}25 \\
75\end{array}$ & 4.33 & 0.12 \\
\hline $\begin{array}{l}\mathbf{2}^{\text {nd }} \text { degree heart block } \\
\text { Yes } \\
\text { No }\end{array}$ & $\begin{array}{l}0 \\
5\end{array}$ & $\begin{array}{c}0 \\
100\end{array}$ & $\begin{array}{l}0 \\
35\end{array}$ & $\begin{array}{r}0 \\
100\end{array}$ & $\begin{array}{l}1 \\
3\end{array}$ & $\begin{array}{c}25 \\
75\end{array}$ & 10.23 & $0.006^{*}$ \\
\hline
\end{tabular}

$* P$ value $<0.05=$ significant,$* * P$ value $<0.001=$ highly significant

- Sinus tachycardia: $H R>100 \mathrm{bpm}$

- Sinus bradycardia: $H R<60$ bpm

- Wide QRS complex: $>0.1 \mathrm{sec}$

- First degree heart block: PR interval >0.24 sec (>6 small squares)

- Second degree heart block: Mobitz type II: each P wave is followed by QRS complex; but occasionally one atrial beat is not conducted to the ventricles (one P wave is not followed by QRS complex).

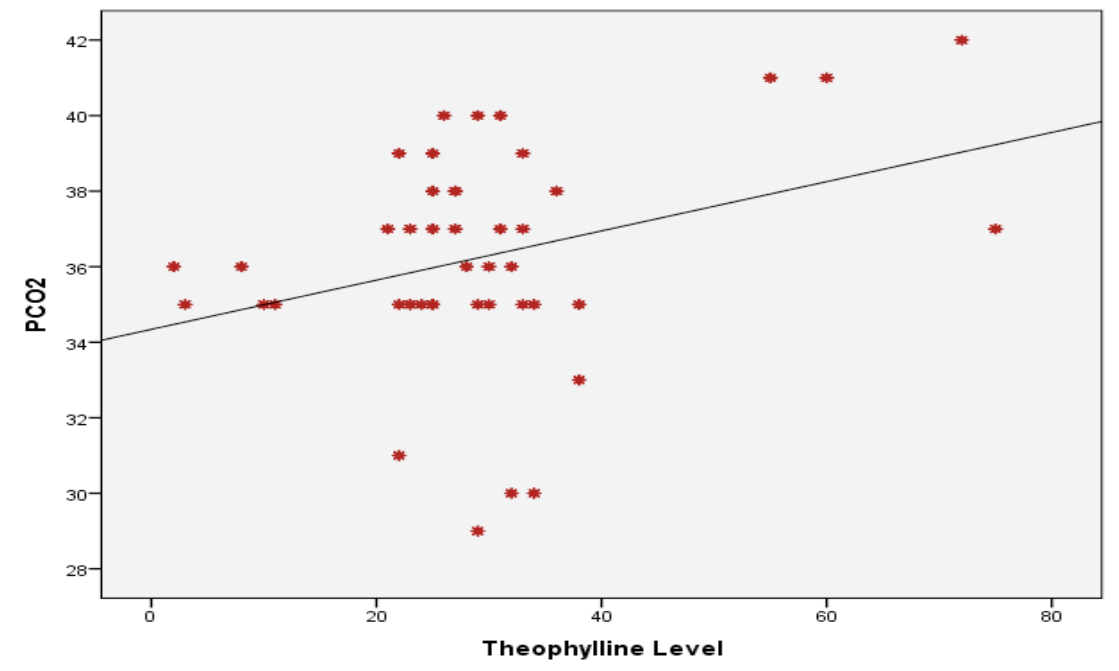

Fig. (1): Curve demonstrating correlation between theophylline level (ug/ml) and PCO2 (mmHg). 


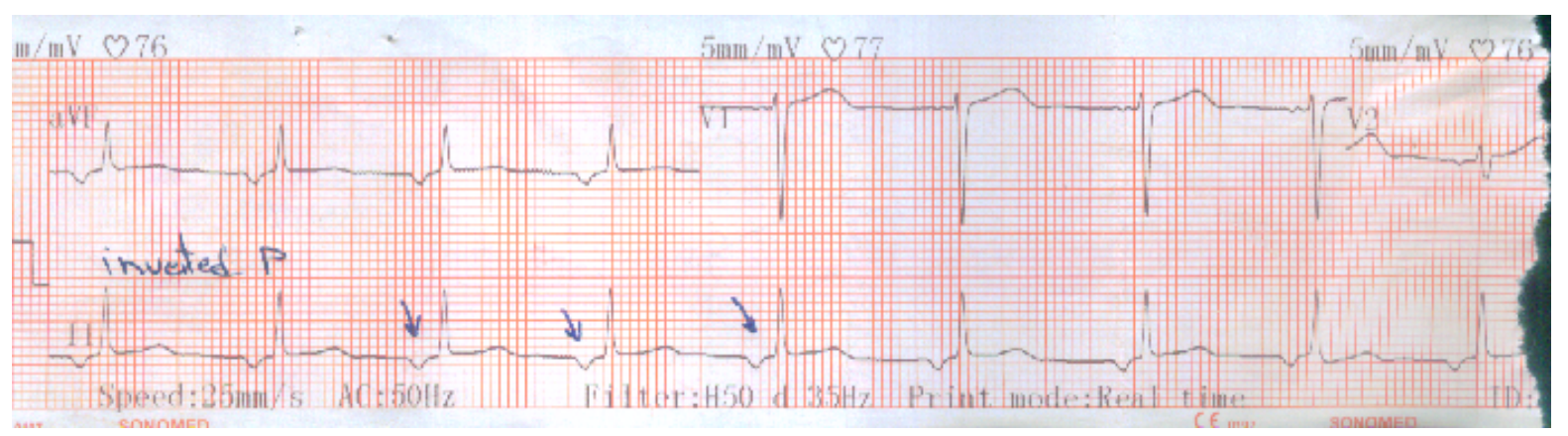

Fig. (2): A photograph of ECG strip showing an inverted $P$ wave in lead II in theophylline intoxicated case.

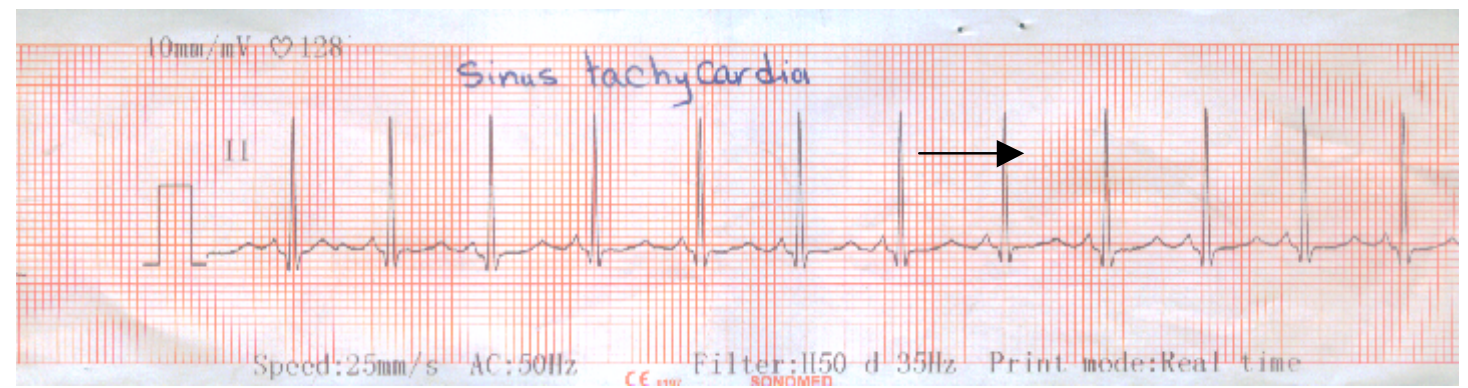

Fig 3: A photograph of ECG strip showing sinus tachycardia: heart rate is $128 \mathrm{beat} / \mathrm{min}$ and regular

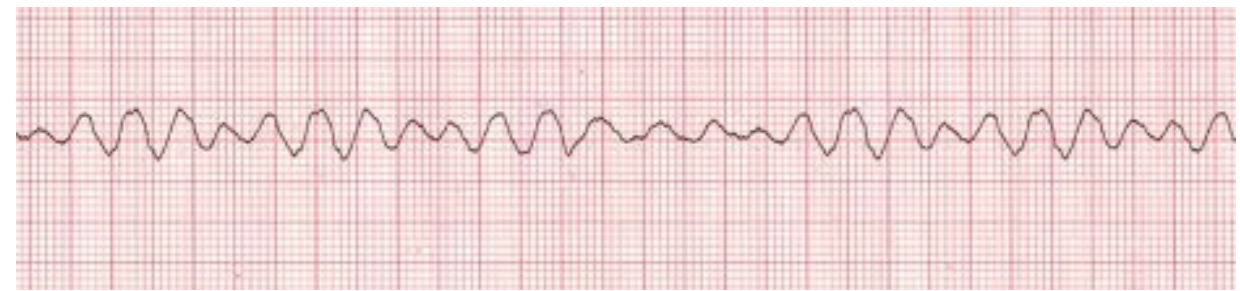

Fig 4: A photograph of ECG strip of a case of theophylline intoxication complicated by VF; no QRS complexes are identified and the ECG is totally disorganized.

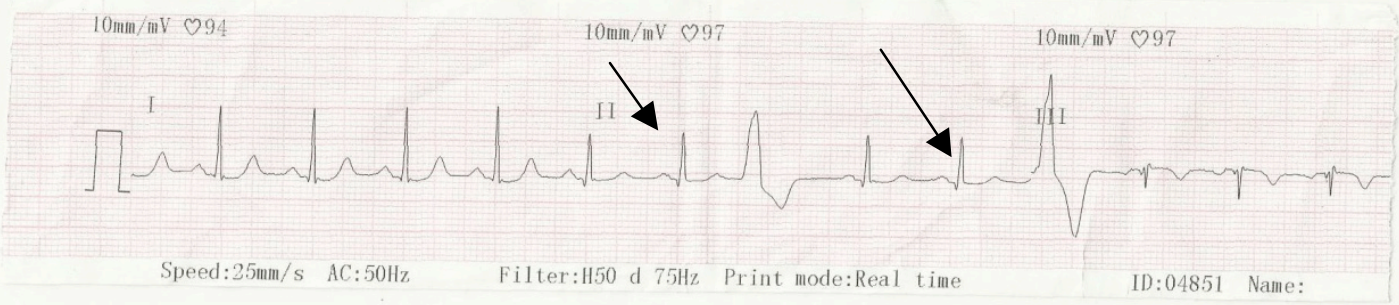

Fig 5: A photograph of ECG strip showing ventricular extrasystoles; in a theophylline intoxicated case\{ note the braod bizarre QRS complexes among the normal sinus beats and the abnormal $T$ waves (ORS complex is about $0.4 \mathrm{~s})\}$.

\section{Discussion}

Theophylline is used to treat asthma and chronic obstructive pulmonary disease. The dose of theophylline is adjusted to maintain blood levels within a certain range. Theophylline toxicity may occur when a person take too much of the medication (Cazzola and Matera, 2007).

The present study revealed that females comprised most of the cases $(77.2 \%)$ and also comprised the majority in suicidal mode of poisoning representing $87.9 \%$ (Table 1and 2 ).

This coincided with Ruda et al., (2006) who stated that suicidal mode was the most common mode of acute intoxication. Also, Yasan et al., (2008) found that higher suicide attempt rates were observed in females compared to the males. On the contrary, Garg and Verma, (2010) found that poisoning cases among males $(80.0 \%)$ dominated over females $(20.0 \%)$, and the majority of cases were male victims of suicidal attempts. Predominance of females can be explained by lower educational level in females, a lower rate of employment and suppression of personal freedom by parents. Family conflicts and parental disagreement played important roles in suicidal attempts (Schmidtke, 1997). Suicidal attempts can be explained by impulsive suicides which are generally motivated by anger, the desire to get even, the wish to frighten or punish others, or the need to avoid intense shame (Aslan et al., 2011). Also oppressive attitude of the husband towards the wife, marriage at young age, and being a housewife 
(not working) have impacts on suicide attempts of women (Bilgin et al., 2007).

The relation between mode of drug poisoning and different age groups was highly significant ( $\mathrm{P}$ value $<0.001$ ), where all cases below 10 years old had taken the overdose accidentally (Table 2).

The predominance of age group $20-<40$ years old in the present study coincided with Gorea et al., (2001) and Gupta and Vaghela,( 2005) who stated that maximum cases belonged to second and third decade of life. Also, Anthony and Kulkarni, (2012) stated that young women in the age group of 21-30 years accounted for $39.5 \%$ of the drug overdose cases, with nearly $50 \%$ being married, and were from an urban background.

As regards age group $<5$ years, this could be explained by the fact that children lack discrimination between harmful and non harmful things. Infants and small children are closer to the ground than older children; in addition, children have a natural exploratory curiosity and put everything in their mouths (Syeda et al., 2006). Lacking of child protection is also another contributing factor (Tanner and Turney,. 2006).

Concerning accidental poisoning in age group $5-<10$ years, it could be due to that this age had increased activities and skills causing more exposure to their environment (Gupta et al., 2003; Kliegman et al., 2008).

In the present study, most of the cases were from rural areas $(65.9 \%)$, while urban cases represented only $34.1 \%$ (Table 1 ). This result was in accordance with the results reported by Adejuyigbe et al., (2002) and Oguche et al., (2007) who found that poisoning was more common among low socioeconomic classes. Also, Garg and Verma, 2010 stated that poisoning cases were more common in rural areas.

On the other hand, Cahfer and Ismail, (2004), who studied cases of acute poisoning, had found that $57.7 \%$ of cases came from city center and $42.4 \%$ of the cases come from rural areas. This contrast may be due to difference in the sociodemographic pattern in the two studies.

This can be explained by the rural nature of Menofiya governorate and low socioeconomic standards associated with low levels of education and culture. Easy availability, extensive use and low cost of the chemicals, all make the population more vulnerable for accidental as well as suicidal poisoning (Unnikrishnan et al., 2005).

On measuring theophylline serum level in the present study cases that had theophylline toxicity, the serum theophylline level ranged between 2-75 $\mu \mathrm{g} / \mathrm{ml}$ with mean value of $29.3 \pm 14.4 \mu \mathrm{g} / \mathrm{ml}$. This level is above therapeutic level as reported by Nolan et al., (2005) and Yin et al., (2012) who stated that theophylline has a narrow therapeutic window with an optimal plasma concentration of $10-20 \mu \mathrm{g} / \mathrm{m}$. Above this concentration, toxic effects such as arrhythmias and convulsions may occur, especially when given rapidly by intravenous injection.
Several other studies had recorded similar theophylline therapeutic levels. Shannon, (1999) reported therapeutic serum concentration of 5$20 \mu \mathrm{g} / \mathrm{ml}$.; Karaman, (1994) and Stoloff, (1994) reported that levels over $15 \mu \mathrm{g} / \mathrm{ml}$ were observed to be frequently toxic and a targeted therapeutic level between $5-15 \mu \mathrm{g} / \mathrm{ml}$ was subsequently proposed. Some researchers argued that the therapeutic level should be between 8-12 $\mu \mathrm{g} / \mathrm{ml}$ (Weinberger et al., 1989). In another study, it has been proposed that it would be easier to adjust the therapeutic level to $8-15 \mu \mathrm{g} / \mathrm{ml}$ (Cheung et al., 2000). Considering all these arguments, the therapeutic range between $8-20 \mu \mathrm{g} / \mathrm{ml}$ was accepted in the present study.

Theophylline serum level between $20-<40$ $\mu \mathrm{g} / \mathrm{ml}$ was reported in $79.5 \%$ of theophylline overdose cases (table 3). This percent was high when compared to Sessler, (1990) who found that $10 \%$ and $2.8 \%$ of 5,557 consecutive serum theophylline concentrations (STCs) measured in the Emergency Departments (ED) over 2 years were greater than $20 \mu \mathrm{g} / \mathrm{ml}$ and greater than $30 \mu \mathrm{g} / \mathrm{ml}$ respectively.

In contrary to the current study results, Yoshikawa,( 2007) who studied 54 cases of theophylline associated seizures (TAS), and measured serum theophylline concentrations at the time of seizure in 42 cases, had found that the mean serum concentrations $(10.79 \mu \mathrm{g} / \mathrm{ml})$ were often within the therapeutic range (range $3.1-27.6 \mu \mathrm{g} / \mathrm{ml}$ ).

On studying clinical manifestations in the cases of the present study, it was found that $80 \%$ of cases with minimal theophylline serum level and all cases of moderate level had vomiting. This can be explained by catecholamine induced gastric acid secretion (Marshall et al., (2004).

This result was similar to that recorded by Altaie et al., (2011) who stated that high blood concentration of theophylline above the therapeutic range may cause nausea, vomiting, arrhythmia, and seizure. Lim et al., (2005) who studied treatment of theophylline toxicity with continuous venovenous haemofiltration, also reported that nausea, vomiting and tachycardia are common signs of theophylline toxicity.

In theophylline overdose cases, none of the cases had convulsions, and only $2.3 \%$ developed loss of consciousness. CNS manifestations of theophylline overdose are mediated by blocking adenosine receptors with elevation of seizure threshold Miura and Kimura, (2000). This result was nearly similar to Visitsunthorn et al., (2001) who found that seizures were found in 1 out of 44cases of their study and were not severe and could be treated with benzodiazepines. On the other hand, Boison, (2011) stated that seizures are potentially severe or fatal complications of theophylline therapy. Also, Yoshikawa (2007) added that TAS is common in pediatric patients less than 5 years of age.

The difference in this study results in comparison to the literature can be due to the inaccuracy of the estimated dose $(32.5 \%$ of the study cases gave history of unknown ingested dose), as the drug was not prospectively administered and the dose information relied on historical data from a witness, 
parent, or the patient. The proconvulsant and convulsant effects of methylxanthines are generally dependant on dose and mode of application (Gaudreault and Harwood, 2005).

In regard to ECG changes, a significant correlation was found between theophylline serum level and sinus tachycardia; which was evident in all cases of moderate toxicity level, $74.3 \%$ of cases with minimal toxicity theophylline serum level, and in $20 \%$ of cases with therapeutic level. $2^{\text {nd }}$ degree heart block was evident in $25 \%$ of cases with moderate toxicity theophylline level (table 7). ECG changes of theophylline can be explained by elevated plasma levels of epinephrine and norepinephrine secondary to theophylline toxicity (Marshall et al., (2004).

The current study results coincided with Yin et al., (2012) found that levels of theophylline above therapeutic levels can cause tachyarrhythmia and cardiac arrest. Salamzadeh et al., (2008) stated that the most common side effect of theophylline toxicity is sinus tachycardia Mohamad et al., (2009) reported similar findings.

In the current study, there was a significant mild negative correlation between theophylline serum level and $\mathrm{P}_{\mathrm{CO} 2}(\mathrm{P}$ value $=0.03)$. This is explained by hyperventilation which may be due to direct stimulation of the respiratory centre (Cheung et al., 2000).

This result was in accordance with Visitsunthorn et al., (2001) who found that acidosis is a common abnormality in theophylline toxicity.

As regards the correlation between theophylline serum level and severity grades of the studied cases according to PSS, it was highly significant. This result agreed with Visitsunthorn et al., (2001) who stated that cardiovascular, gastrointestinal and neurological symptoms from theophylline toxicity were directly related to increased plasma theophylline levels. Similar results were recorded by Gaudreault and Harwood, (2005).

\section{Conclusion}

A significant relation was found between theophylline serum level and sinus tachycardia; which was evident in all cases of moderate toxicity level, $74.3 \%$ of cases with minimal toxicity theophylline serum level. A highly significant direct relation between theophylline serum level and severity grades of the studied cases according to poison severity score (PSS).

A significant mild negative correlation between theophylline serum level and $\mathrm{P}_{\mathrm{CO} 2}$ was found; so it is recommended to apply serum theophylline level in approach to manage a case of theophylline intoxication.

\section{References}

Adejuyigbe EA, Onayade AA and Senbanjo IO (2002): Childhood poisoning at the Obafemi Awolowo University Teaching Hospital, IleIfe, Nigeria, Niger J Med, 11(4):183-6
Altaie N, Malik S and Robertson S (2011): Theophylline Toxicity- A Forgotten Entity. BJMP; 4(1):a404

Anthony L and Kulkarni C (2012): Patterns of poisoning and drug overdosage and their outcome among in-patients admitted to the emergency medicine department of a tertiary care hospital, Indian J Crit Care Med.;16:1305

Aslan S, Emet M, Cakir Z et al. (2011): Suicide attempts with amitriptyline in adults: a prospective, demographic, clinical study, Turk J Med Sci doi:10.3906/sag-0908-227,; 41(2): 243-249

Bilgin M, Cenkseven F and Satar S (2007): An analysis of parent-female adolescent relationships in female adolescent suicides Crisis; 28: 190-7

Boison D (2011):10 Methylxanthines, seizures and excitotoxicity, Handb Exp Pharmacol.; (200): 251-266. doi:

Cahfer $G$ and Ismail $H$ (2004): Cases of Acute Poisoning in Southeast Anatolia of Turkey; 31(2):37-45

Cazzola M and Matera MG (2007): The additive effect of theophylline on a combination of formoterol and tiotropium in stable COPD: a pilot study, Respir. Med.; 101(5): 957-962

Cheung L, Tsoi L and Chung C (2000): Severe headache as a chief presentation of theophylline intoxication, Hong Kong j. emerg. med.; 7(2):104-106

Elliott AC and Woodward WA (2007): SPSS (Statistical package for the social sciences, SAGE puplications (California, London and New Delhi), printed in USA

Fruchtengarten L (2006): Handling Poison information, Poison prevention week May 28 to June 4, Kingston, Jamaica, data show

Gaudreault P, Harwood N, ( 2005): Methylxanthines, Toxicology. In: Clinical Practice of Emergency Medicine. $4^{\text {th }}$ ed.:1649-1652.

Gorea RK, Dalal JS, Gargi J et al., (2001): Pattern of Poisoning in Punjab.J Punjab Acad Forensic Med Toxicol.; 1: 6-8

Gupta BD and Vaghela PC (2005): Profile of Fatal Poisoning in and around Jamnagar. Journal of Indian Academy of Forensic Medicine; 27(3): 145-148

Gupta SK, Peshin SS et al., (2003): A Study of Childhood Poisoning at National Poisons Information Centre, All India Institute of Medical Science, New Delhi. J Occup Health; 45: 191-196

Hansen N, Niederberger ASP, Guzzella L et al., (2009): A method for Handling Uncertainty in Evolutionary Optimization with Application to Feedback Control of Combustion, to appear in IEEE Transactions on Evolutionary Computation, IEEE Press.

Hoffman RS (2006): Fluid, electrolyte, and acid-base principles. In: Goldfrank L R, Howland M A, Hoffman R S et al., editors, Goldfrank's 
toxicologic emergencies, 7th edition. New York: $\mu$ graw-Hill; p. 2170

Intervention,London: Jessica Kingsley

Karaman Ö (1994): Bir ilaç deđerlendirmesi: teofilin. 〈laç ve Tedavi Dergisi; 7: 55-62

Kliegman RM, Behrman RE, Jenson HB et al., (2008): Nelson Textbook of pediatrics, 18th edition, pub. Philadelphia, USA; chapter 52,53,54,55 and 60, p. $267-319,1-4$.

Lim S, Tan SH, Ng TG et al., (2005): Successful treatment of theophylline toxicity with continuous venovenous haemofiltration, Crit Care and Shock.; 8 (4): 96-97

Lionte C, Bologa C and Sorodoc L (2012): Toxic and Drug-Induced Changes of the Electrocardiogram, Advances in Electrocardiograms - Clinical Applications, PhD. Richard Millis (Ed.), In Tech, Available from: http://www.intechopen.com/books/advances

Marshall H, Emerman CL, Tintinalli J(2004) : Theophylline, Toxicology and Pharmacology. In: Emergency Medicine, A Comprehensive Study Guide. $6^{\text {th }}$ ed.:1098-1101

Miura T, Kimura K (2000): Theophylline-induced convulsions in children with epilepsy. Pediatrics 2000; 105:920

Mohamad N, Abd Halim N N, Ahmad R et al., (2009): Theophylline toxicity: A case report of the survival of an undiagnosed patient who presented to the emergency department, Malaysian Journal of Medical Sciences; 16 ( 2):33-37

Nolan JP, Deakin CD, Soar J et al. (2005): European Resuscitation Council guidelines for resuscitation 2005. Section 4. Adult advanced life support. Resuscitation; 67(1):S39-8

Oguche S, Bukbuk DN and Watila IM (2007): Pattern of hospital admissions of children with poisoning in the Sudano- Sahelian North eastern Nigeria, Niger J Clin Pract.; 10 (2):111-5

Persson HE, Sjoberg GK, Haines JA et al., (1998): Poisoning severity score. Grading of acute poisoning, J Toxicol Clin Toxicol.; 36:205-13

Reilly EF and Stawicki SP (2008): ICU Corner: Highyield toxicology: Essential facts for the critical care boards, OPUS 12 Scientist 2, (1):33-38

Ruda A, Ilenuta D et al., (2006): Acute poisoning cases admitted in ICU II toxicology emergency clinical hospital Bucharest in 10 years (19982007); Toxicology letters 180S, P C129-C130

Salamzadeh J, Dadashzadeh S, Habibi M et al., (2008): Serum and Saliva Theophylline Levels in Adult Outpatients with Asthma and Chronic Obstructive Pulmonary Disease (COPD): A Cross-Sectional Study, Iranian Journal of Pharmaceutical Research, 7 (1): 83-87

Schmidtke A (1997): Perspective: suicide in Europe. Suicide Life Threat Behav: 27, 127-36

Sessler CN (1990): Theophylline toxicity: Clinical features of 116 consecutive cases, The
American Journal of Medicine, 88, (6): 567576

Shannon M (1999): Life-Threatening Events after Theophylline Overdose, a 10-Year Prospective Analysis in Archive Internal Medicine, 159, (9): 989-994

Sköld AC (2000): Teratogenicity as a consequence of drug-induced embryonic cardiac arrhythmia. Common mechanism for almokalant, sotalol, cisapride, and phenytoin via inhibition of IKr. Acta Universitatis Upsaliensis. Comprehensive Summaries of Uppsala Dissertations from the Faculty of Pharmacy 235. 51

Stoloff SW (1994): The changing role of theophylline. American Family Physician; 49: 839-844

Syeda A, Gulati R et al., (2006): Risk Factors in Acute Poisoning in Children- A Retrospective Study, Kuwait Medical Journal; 38, (1): 33-36

Tanner, K and Turney, DJ. ( 2006):'Therapeutic interventions with children who have experienced neglect and their families in the UK', in McAuley, C, Pecora, PJ and Rose, W (Eds.), Enhancing the Well-Being of Children and Families through Effective Interventions, (pp. 118-130), Jessica Kingsley

Torraca L and Wang RY (1998): Methylxanthines (Theophylline and Caffeine) in Emergency Toxicology by Viccellio $P$, Brent $J$ and Hoffman R S et al., 2th edition, chapter 50, p.775, Philadelphia

Unnikrishnan B, Singh B and Rajeev A (2005): Trends of Acute Poisoning in South Karnataka. Kathmandu Univ Med J. 3(2):149-54

Verma AK and Roach P (2010): The interpretation of arterial blood gases, Australian Prescriber, 33 (4): $124-9$.

Visitsunthorn N, Udomittipong $\mathrm{K}$ and Punnakan L (2001): Theophylline Toxicity in Thai Children, Asian Pacific Journal of Allergy and Immunology 19: 177-182

Weinberger M (1989): The value of theophylline for asthma. Ann Allergy; 63: 13

Yasan A, Danis R, Tamam L et al., (2008): Sociocultural features and sex profile of the individuals with serious suicide attempts in southeastern Turkey: a one-year survey. Suicide Life Threat Behav; 38: 467-80

Yin H, Meng X, Su H et al., (2012): Electrochemical determination of theophylline in foodstuff, tea and soft drinks based on urchin-like CdSe microparticles modified glassy carbon electrode, Food Chemistry; 134 (2):12251230

Yoshikawa H (2007): First-line therapy for theophylline-associated seizures. Acta Neurol Scand: 115 (186): 57-61

Zhou M, Guan C, Chen G et al., (2005): Determination of theophylline concentration in serum by chemiluminescent immunoassay. J Zhejiang Univ Sci B, 6 (12): 1148-1152 


\section{الملخص العربي

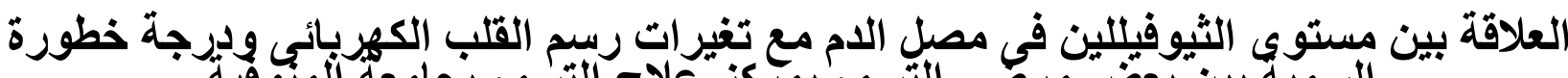

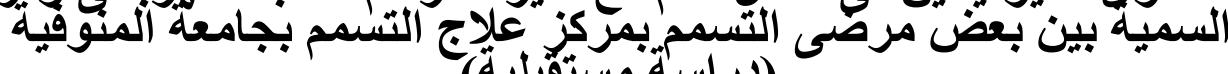 (دراسة مسنثقبلية)}

صفاء عبد الظاهر أمين و أميرة محمد الصعيدي و سامي عبد الهادي حماد و نجوى محمود حبيب1

هنالك العديد من السموم و الأدوية التي يمكن أن تسبب تغير ات في رسم القلب الكهربائي عند أخذها

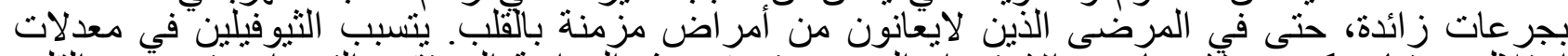

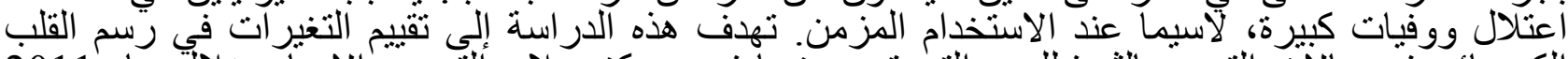

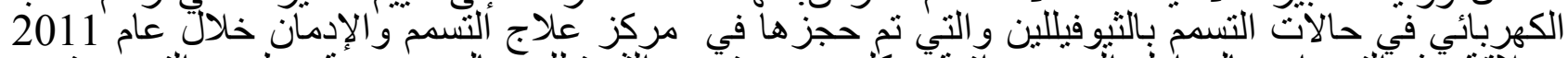

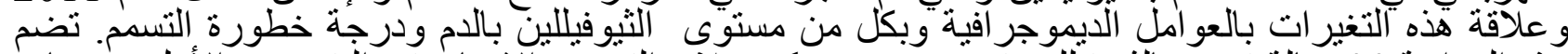

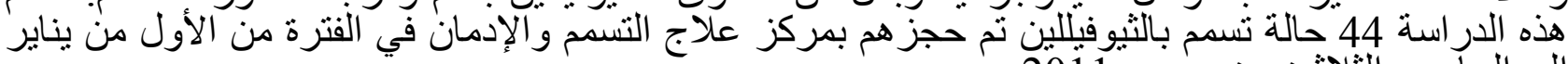

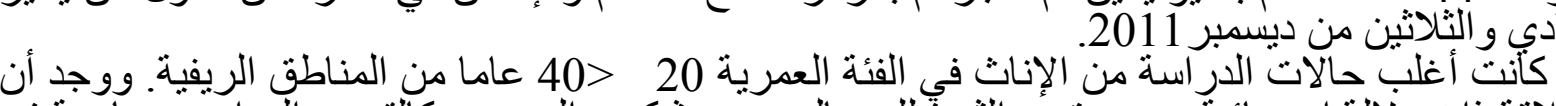

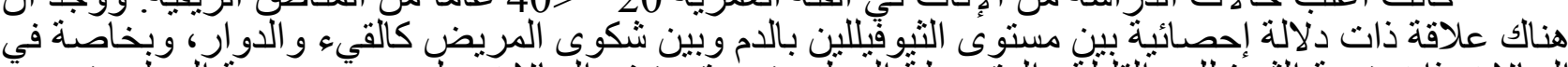

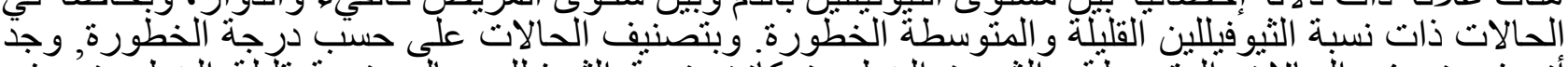

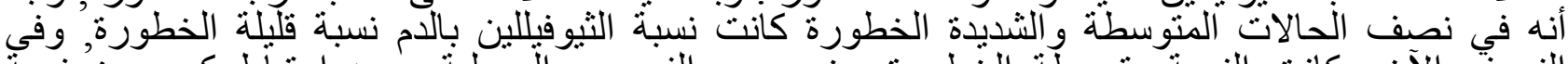

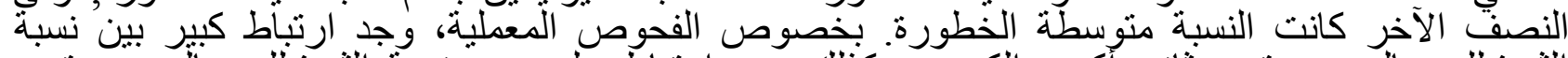

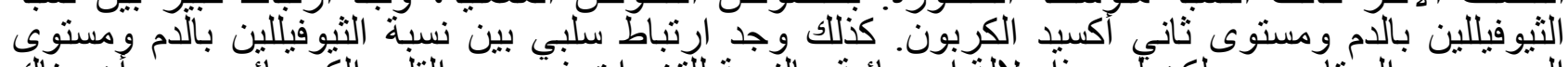

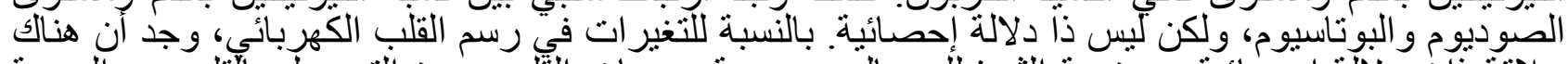

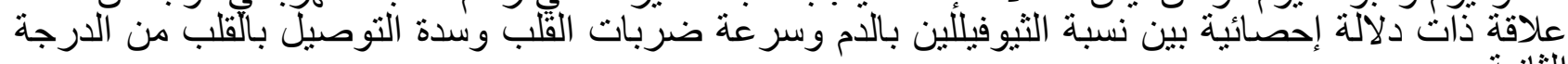
نستخلص من هذه الدراسة وجود علاقة طردية بين علامات و أعر اض التسمم بالثيوفبللين ومستو اه الثانية. بالام.

1 قسم الطب الثرعي و السموم الإكلينيكية كلية الطب جامعة المنوفية 